\title{
Research on Development of the Song Genre Paintings \& Artists
}

\author{
Rong $\operatorname{Tan}^{1}$ \\ ${ }^{1}$ College of Fashion \& Art Design, Donghua University, Shanghai, China \\ Correspondence: Rong Tan, College of Fashion \& Art Design, Donghua University, Shanghai, China. E-mail: \\ tanrong19862004@163.com
}

Received: April 22, 2014 Accepted: May 4, 2014 Online Published: June 25, 2014

doi:10.5539/ass.v10n13p202 URL: http://dx.doi.org/10.5539/ass.v10n13p202

\begin{abstract}
Due to that many historical documents of China recording the life of emperors and people from upper class in ancient times with limited ones recording that of people from middle and lower classes, genre paintings have played as the important materials for the research on the ancient societies. This paper begins with the analysis on the concept and development progress of the genre paintings; and analyzes on the three types of painting producers by the combination of the surviving genre paintings and relative documents. The analysis on those painting producers will be helpful for the understanding of paintings' contents and implied meanings, acting as one of the indispensable steps for the study of the Song genre paintings.
\end{abstract}

Keywords: Song genre paintings, Artists, painting producers

\section{Concept of Genre Painting}

Genre painting, appeared in historical records, haven't been defined explicitly. It was the emergence of various lexicons in modern times that has led to the concept of genre painting. Just as Shen Roujian pointed out in his China Art Dictionary, Genre Painting is one kind of figure painting themed as social morality and life style (Roujian S, 1987, p5). According to Encyclopedia of China, "Genre Painting is defined as category of paintings centered by figures to demonstrate common customs" (Editorial Office of Encyclopedia of China, 2013, p. 396). Based on the concepts mentioned above, the author believes that genre painting is a kind of painting works that portrays social customs, focusing on the daily life of the grass-root class.

\section{Development Progress of Genre Painting}

Paintings portraying scenes of the underclass had existed prior to the Song Dynasty, instead of independent category. After undergoing nearly 800 years of development, the genre paintings had enjoyed its prosperity in the Song Dynasty.

\subsection{Genre Paintings Prior to the Song Dynasty}

From the perspective of subject selection, the earliest genre painting shall be the portrait brick in the Han Dynasty. A large number of portrait bricks have been unearthed in Sichuan, Jiangsu, Henan and Shandong, covering the subjects of all aspects of the social life, including farming, feast, dancing, acrobatics and hunting. Figure 1.

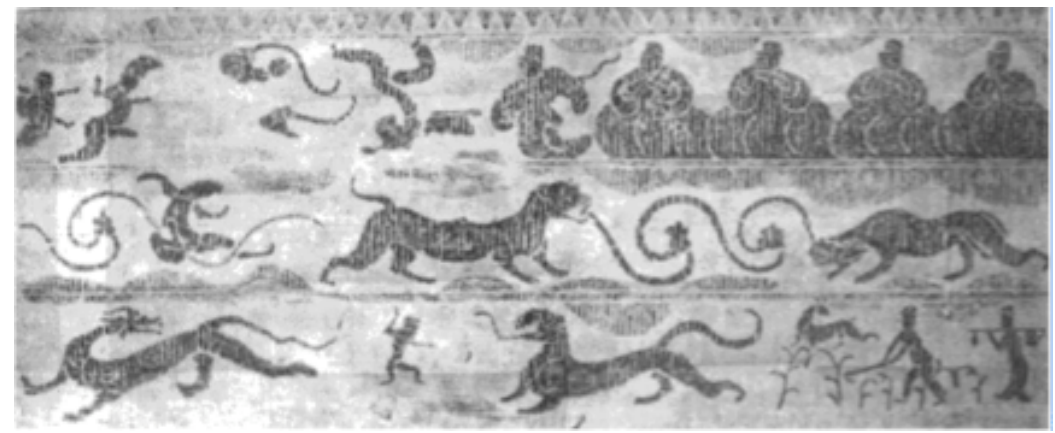

Figure 1. Portrait Brick Unearthed from Mausoleum of Xing Ying in the Han Dynasty (Farming Scene in the Bottom) 
There are less genre paintings in the Jin Dynasty, represented by 'Rural Genre Painting' by Tian Sengliang and 'The Genre Painting of Beauties' by Liu Tian. The genre paintings, with Tian Sengliang as the representative, are the extension and continuation the stone relieves and portrait bricks in the Han Dynasty in terms of contents, featuring the realistic style; and the 'The Genre Painting of Beauties' by Liu Tian had started transforming the painting focus on artistic appreciation.

In the Tang Dynasty, despite that paintings still emphasized on emperors and people from the upper class, there had been some paintings describing the scenes of farming or hunting, with the increased number of paintings on grass-root class gradually. According to Catalogue of Famous Paintings of Past Dynasties, there are 'Rural Genre Painting' by Han Huang, and 'Farming in Remote Mountains', 'Food Delivery' and 'Fishing' by Wang Wei.

\subsection{Reasons of Song Genre Painting Prosperity}

Compared to the previous dynasties, the Song Dynasty featured the diversified subjects as its greatest progress. All aspects of common people, including food, clothing, housing and transformation, had become the subject sources of the genre paintings of the Song Dynasty, resulted from its unique social background. Firstly, the establishment of the imperial examination system and the Imperial Academy had given opportunities to people from the lower class to have access to the upper society. For instance, Yan Wengui was just a street hawker who was familiar with the daily life of common people, before entering into the Imperial Academy. People like Yan had brought the life-oriented aesthetic taste characterized by secularization into the upper society after their joining in the Imperial Academy, exerting influences on the overall development of the painting style. This is the important reason leading to the considerable increased genre paintings in the Song Dynasty. Secondly, the prosperous market economy in the Song Dynasty had made the genre paintings available to circulate as commodities. There were specific painting markets (Huarui L, 1993) in the Song Dynasty, along with the existing of vendors (Ruoxu G, 2000, p. 235) and investors (Chun D, 2000, pp. 420-421) who made a living by scalping paintings. Thirdly, artists of the Imperial Academy had also portrayed the customs on imperial orders. They had to produce the folk scenes into pictures for the emperors to better understand the production and living of ordinary people.

\subsection{Subjects \& Surviving Number of the Song Genre Paintings}

The genre paintings of the Song Dynasty mainly portrayed the scenes of market, festival, children at play, excursion, cattle pasturing, entertainment and sacrifice ceremony, composing an encyclopedia of civilian life. The Song genre paintings are divided into four parts by subjects:

\subsubsection{Farming \& Weaving}

Paintings falling into the category of "Farming \& Weaving" don't specifically indicate those ones titled 'Farming \& Weaving', but the painting works by the painters of the Song Dynasty describing the daily scenes of farming, weaving, fishing, hunting and cattle pasturing of the working people. This paper divides the paintings of "farming \& weaving" into four types, based on production categories, namely farming, silkworm breeding and weaving, fishing and hunting, cattle pasturing. 'Farming \& Weaving' mainly describes the scenes of farmers working in the field; 'Silkworm Breeding \& Weaving' describes a series of images of a whole progress, from mulberry leaf harvest and silkworm breeding to weaving; 'Fishing \& Hunting' describes the scenes of farmers in fishing or hunting; 'Battle Pasturing' expresses the scenes of cowboys pasturing. There are 45 pieces of surviving paintings in total, as Table 1 .

Table 1. Working scenes in the song genre paintings

\begin{tabular}{llll}
\hline NO. & Title & Painter & Collector \\
\hline 1 & Spinning Wheel & Wang Juzheng & Beijing Palace Museum Collection \\
2 & Farming \& Weaving & Lou Shu & National Museum of China \\
3 & Farming \& Harvest & Yang Wei & Beijing Palace Museum Collection \\
4 & Spinning & Liu Songnian & Taibei Palace Museum Collection \\
5 & Spinning & Anonymous & Beijing Palace Museum Collection \\
6 & Ironing & Mao Yi & Taibei Palace Museum Collection \\
7 & Sewing \& Mending & Liu Songnian & Taibei Palace Museum Collection \\
8 & Moxibustion & LI Tang & Beijing Palace Museum Collection \\
9 & Tea Cooking & Liu Songnian & Taibei Palace Museum Collection \\
10 & Tea Tasting & Anonymous & Beijing Palace Museum Collection
\end{tabular}


11 Returning from Fishing

12 Angling in the Cold River Alone

13 Fishing in the Cold River

14 Fishing Farmer

15 Fishing Farmer

16 Fishing in Winter

17 Happy Fishing

18 Singing Farmer

19 Farmers' Joyful Harvest

20 Sheepherding

21 Horse Washing

22 Returning by Riding a Horse

23 Calf

24 Calf
Calf \& Cow

Pasturing along the River at the Foot of a Hill

Returning from Pasturing along a River

Pasturing in the Autumn Forest

Pasturing in the Autumn Field

Pasturing in the Autumn Forest

Pasturing in Snow Day

Pasturing along Stream Banks in Snow

Day

Returning from Pasturing along Stream

Banks

Returning from Pasturing

Returning from Pasturing

Cattle Pasturing

Cattle Pasturing

Cattle Pasturing

Cattle Pasturing

Cattle Pasturing

Cattle Pasturing

Cattle Pasturing

Cattle Pasturing

Cattle Pasturing

Cattle Pasturing
Liang Kai

Ma yuan

Yan Wengui

Anonymous

Anonymous

Anonymous

Anonymous

Ma Yuan

Li Song

Anonymous

Anonymous

Anonymous

Zhao Ji

Li Tang

Anonymous

Qi xu

Qi xu

Liu Songnian

Yan Ciping

Anonymous

Li Di

Anonymous

Anonymous

Anonymous

Anonymous

Mao Yi

Wang Zao

Zhi Rong

Anonymous

Anonymous

Anonymous

Anonymous

Anonymous

Anonymous

Li Shi
Freer Gallery of Art

Tokyo National Museum

Taibei Palace Museum Collection

Taibei Palace Museum Collection Taibei Palace Museum Collection Beijing Palace Museum Collection Beijing Palace Museum Collection Beijing Palace Museum Collection Taibei Palace Museum Collection Shanghai Museum

Taibei Palace Museum Collection Beijing Palace Museum Collection Taibei Palace Museum Collection Taibei Palace Museum Collection Taibei Palace Museum Collection Beijing Palace Museum Collection

Taibei Palace Museum Collection Taibei Palace Museum Collection Izumiya Museum in Japan Beijing Palace Museum Collection Museum Yamato Bunkakan Beijing Palace Museum Collection

Freer Gallery of Art

Beijing Palace Museum Collection Freer Gallery of Art

Beijing Palace Museum Collection

Private collector in Japan

Private collector in Japan

Beijing Palace Museum Collection

Museum of Fine Arts Boston

Municipal Museum of Fine Art

Taibei Palace Museum Collection

Taibei Palace Museum Collection

University of Michigan

Cleveland Museum of Art

\subsubsection{Picture of Market}

Table 2. Market scenes in the song genre paintings

\begin{tabular}{llll}
\hline NO & Title & Painter & Collector \\
\hline 1 & Knick-knack Peddler & Li Song & Beijing Palace Museum Collection \\
2 & Knick-knack Peddler & Li Song & Metropolitan Museum of Art \\
3 & Knick-knack Peddler & Su Hanchen & Taibei Palace Museum Collection \\
4 & Knick-knack Peddler & Su Hanchen & Taibei Palace Museum Collection \\
5 & Knick-knack Peddler & Qian Xuan & Taibei Palace Museum Collection \\
6 & Knick-knack Peddler & Anonymous & Taibei Palace Museum Collection \\
7 & Riverside Scene at Qingming Festival & Zhang Zeduan & Beijing Palace Museum Collection \\
\hline
\end{tabular}


The rapid economic development of the Song Dynasty had caused the increased number of genre paintings describing the business scenes, such as Riverside Scene at Qingming Festival by Zhang Zeduan and Knick-knack Peddler by Li Song, which had both demonstrated the developed market economy and the social reality in the Song Dynasty. For instance, some paintings of the Song Dynasty were used for praying or decoration, leading to the luxurious clothes dressed by the figures; instead, the 'Market' describes the markets in which people of the Song Dynasty conducted transactions, with the clothes of peddlers and purchasers more realistic than those in other painting works. Consequently, those scenes described in the paintings falling into the category of 'Market' have provided reliably visual documents for the costume studies today. There are 7 pieces of surviving genre paintings of the Song Dynasty themed market, as shown in Table 2.

\subsubsection{Pictures of Children at Play}

Table 3. Scenes of children at play in the song genre paintings

\begin{tabular}{|c|c|c|c|}
\hline NO & Title & Painter & Collector \\
\hline 1 & Children at Play in Spring & Anonymous & Beijing Palace Museum Collection \\
\hline 2 & $\begin{array}{l}\text { Children at Play in Dragon Boat } \\
\text { Festival }\end{array}$ & Su Hanchen & Taibei Palace Museum Collection \\
\hline 3 & Children at Play in Yard & Anonymous & Beijing Palace Museum Collection \\
\hline 4 & Children at Play in Yard & Su Hanchen & Taibei Palace Museum Collection \\
\hline 5 & Children at Play in Yard & Su Hanchen & Taibei Palace Museum Collection \\
\hline 6 & Children at Play in Yard & Anonymous & Beijing Palace Museum Collection \\
\hline 7 & $\begin{array}{l}\text { Children at Play around Banana Trees } \\
\& \text { Rockery }\end{array}$ & Anonymous & Beijing Palace Museum Collection \\
\hline 8 & $\begin{array}{l}\text { Children at Play under the Shadow of } \\
\text { Banana Tree }\end{array}$ & Anonymous & Beijing Palace Museum Collection \\
\hline 9 & Children at Play & Su Hanchen & Boston Museum of Fine Arts \\
\hline 10 & Children at Play & Su Hanchen & Taibei Palace Museum Collection \\
\hline 11 & Children at Play & Anonymous & Taibei Palace Museum Collection \\
\hline 12 & Children at Play & Su Hanchen & Taibei Palace Museum Collection \\
\hline 13 & Children at Play around the Lotus Pond & Anonymous & Boston Museum of Fine Arts \\
\hline 14 & Children \& Cats & Anonymous & Boston Museum of Fine Arts \\
\hline 15 & A Hundred Children & Anonymous & Cleveland Museum of Art \\
\hline 16 & Children Taking a Shower & Anonymous & Freer Gallery of Art \\
\hline 17 & Children Taking a Shower & Anonymous & Freer Gallery of Art \\
\hline 18 & Children at Play & Su Hanchen & Taibei Palace Museum Collection \\
\hline 19 & Children \& Sheep & Su Hanchen & Taibei Palace Museum Collection \\
\hline 20 & Children at Play in Bushes & Su Hanchen & Taibei Palace Museum Collection \\
\hline 21 & Children at Play Dragon Boat Festival & Su Zhuo & Taibei Palace Museum Collection \\
\hline 22 & Children Bar-tacking & Anonymous & Taibei Palace Museum Collection \\
\hline 23 & Children at Play in Winter & Anonymous & Taibei Palace Museum Collection \\
\hline 24 & Children Playing Games & Anonymous & Taibei Palace Museum Collection \\
\hline 25 & Children in Spring & Su Hanchen & Taibei Palace Museum Collection \\
\hline 26 & Children Sending Greetings & Qian Xuan & Taibei Palace Museum Collection \\
\hline
\end{tabular}

Prior to the Song Dynasty, there were less paintings themed children at play. However, since the beginning of the Song, the category of genre paintings themed children at play had gradually developed. From the perspective 
of picture expression, paintings of this category can be divided into two parts: paintings for praying for family, and paintings for decoration used as folding screens. Due those functions, the clothes dressed by the figures in those paintings feature luxury, made of leno or silks or satins. However, those paintings could still reflect the social reality of the Song Dynasty to some extent. For instance, Reminiscence of Wulin mentioned that the colored flags used in the celebrations of the Song Dynasty were made of triangle color materials and peacock feathers; researchers of the later generations, who once imagined the style of those flags, didn't learn the style of the flags clearly until seeing the colored flags played by the children in the painting titled 'Children at Play in Winter'. The size of the colored flags described in those paintings is smaller than the flags used normally, bur sharing the similar triangle shape, decorated by peacock feathers at the top of the flagpole. Therefore, the genre paintings portraying the scenes of children at play, totaled 26 pieces handed down from ancient times (as shown in Table 3), are the important materials for the research on the history of the Song Dynasty.

\subsubsection{Pictures of Entertainment \& Acrobatics}

There are many documents recording the entertainment spirit of people of the Song Dynasty. Many forms of art and entertainment to our knowledge today, such as novel, drama even acrobatics, were all sourced or flourished from the Song Dynasty. The entertainment spirit of people of the Song Dynasty was not only demonstrated from people's daily life, but many entertainment links added in the fiestas. For instance, the Yanshe Etiquette, used as the various etiquettes prior to the performance of archery, was aimed at promoting the traditional Chinese culture characterized by treating people with courtesy, as a grandly serious form of etiquette in the Tang Dynasty. However, this ceremony was added by various pieces of music played by music workshops or poetic drama live shows. This had shown that people of the Song Dynasty didn't treat Yanshe Etiquette as a real form of etiquette, but another form of entertainment. Moreover, the Jinming Pool in the Northern Song Dynasty can also demonstrate their entertainment spirit. The pool, originally dig for exercising the battles fought on the sea, river or lake, was transformed into the most flourishing entertainment places, even more busy than the special entertainment place named "Wazi". And it was people's love of entertainment that resulted in the emergence of the specific category of genre paintings portraying the scenes of the entertainment. Table 4

Table 4. Scenes of Entertainment in the Song Genre Dynasty

\begin{tabular}{llll}
\hline NO. & Title & Painter & Collector \\
\hline 1 & Skull Puppet Show & Li Song & Beijing Palace Museum Collection \\
2 & Masked Dance & Anonymous & Beijing Palace Museum Collection \\
3 & Poetic Drama (Selling Eye drops) & Anonymous & Beijing Palace Museum Collection \\
4 & Poetic Drama (Beating the Colored & Anonymous & Beijing Palace Museum Collection \\
& Drum) & \\
\hline
\end{tabular}

\section{Analysis on Painting Producers of the Song Genre Paintings}

Producers of the Song genre paintings are mainly consisted of three groups: folk painters; artists of the Imperial Academy; government officials and monks of the Song Dynasty.

\subsection{Folk Painters}

From the perspective of the inscriptions on the surviving paintings, there were fewer paintings produced by folk painters; however, it is not the case. The market economy of the Song Dynasty had begun to take shape; the access of paintings into the market as commodities had indicated that main producers of the Song paintings were doomed to be changed from the former scholars and imperial artiest to the commercial painters in folk painting workshops; however, due to that most of their works circulated into the market as commodities without signatures, there were few historical documents recording their information, and this is one of the reasons that there are so many surviving Song paintings without painters' signatures, e.g. 'Children at Play in Yard', 'Children at Play in Spring' are those paintings without inscriptions produced by folk painters, Fig.2 and Fig. 3. 


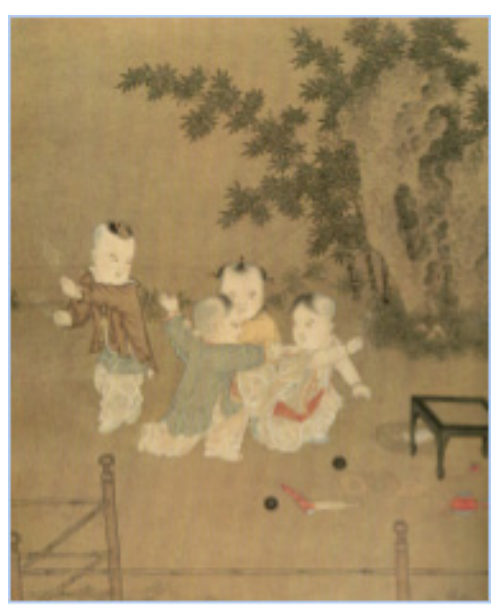

Figure 2. Anonymous: children at play in yard (Taibei Palace Museum Collection)

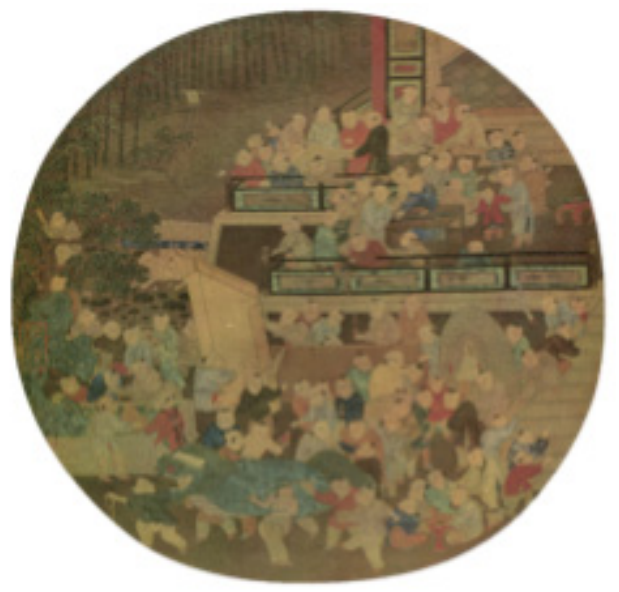

Figure3. Anonymous: children at play in spring (Beijing Palace Museum Collection)

\subsection{Artists of Imperial Academy}

The rulers of the Song Dynasty emphasized on the important role played by "customs" in governing a state. Therefore, most of the producers of the Song genre paintings are the artists of the Imperial Academy. For instance, according to Historical Record of Eastern Han Dynasty, the emperors often summoned government officials to ask them about the living conditions of local people (Yi F, 1927, p228). Sometimes, those officials may produce the scenes of folk life into pictures for emperors' reading; and the production of those pictures were assigned to the artists of the Imperial Academy.

Besides for emperors' understanding of folk scenes in the royal court, the genre paintings themed farming and weaving also played as the tool of social education and guidance, showing people how to farm and produce, as in Fig. 4. The first piece of Farming \& Weaving, produced by Lou Shu in the Sothern Song Dynasty, is reserved till now on the basis of multiple times of copying and reprinting. Besides Lou's version, the surviving paintings themed farming and weaving boast various versions. During the Yuan and Ming Dynasties, the growing methods of crops were produced into images by the governments of various prefectures and counties, to guide people's agricultural production. During the Qing Dynasty, the paintings themed farming and weaving became more and more popular, because that all the emperors of the past dynasties had ordered to produce those paintings and use them as royal decorations, implying peace and prosperity, showing that the paintings themed farming and weaving were very important in the ancient China focusing on agriculture.

To produce the scenes of civil life or farming and weaving, painters had to deeply understand the folk life. Thus, the Imperial Academy recruited folk talents to work for the academy, e.g. Mao Yi and Yan Wengui. The painters coming from the grass root class, although working for the emperors, would never remove their family backgrounds from the lower class; besides, their long-term living environments and knowledge structures had 
resulted in the secular style of their paintings (Shaoqing L, 2010). Based on those reasons mentioned above, most of surviving Song genre paintings were produced by the artists of Imperial Academy.

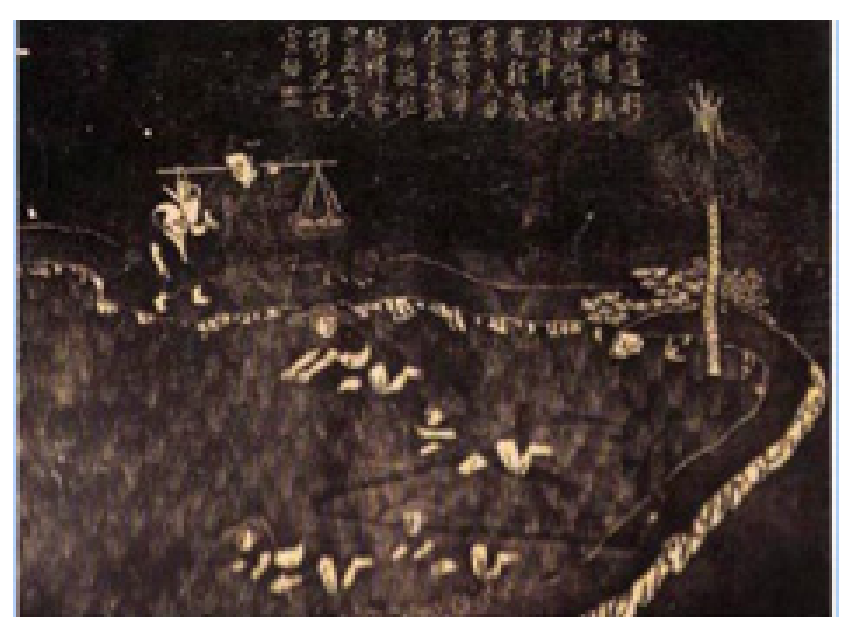

Figure 4. Lou Shu: farming \& weaving (National Museum of China)

\subsection{Part of Government Officials and Monks of the Song Dynasty}

Besides the folk painters and artists of the Imperial Academy, another group of producers of the Song Genre Paintings was consisted of government officials and monks. For instance, Wang Zao, Governor of Prefecture, and Li Di, Prime Minister during the times of Song Renzong, had produced fewer genre paintings, compared to the number of their landscape paintings, most of which had described the rural scenery, such as 'Returning from Pasturing' and 'Cattle Pasturing'. Besides expressing their yearning for countryside, government officials and monks also produced paintings themed cattle pasturing to eulogize the spring. People in the ancient times believed that the implied meaning of cattle in spring was the beginning of agriculture promotion and spring ploughing; consequently, they usually purchased paintings of farm cattle during Beginning of Spring (a Chinese solar term), to express their greeting of spring and pray for a good harvest year. Government officials and monks wouldn't sell the paintings themed cattle pasturing in the paining market, but they would also produce those paintings to express their appreciation of spring and their love of the nature. Fig.5 and Fig.6

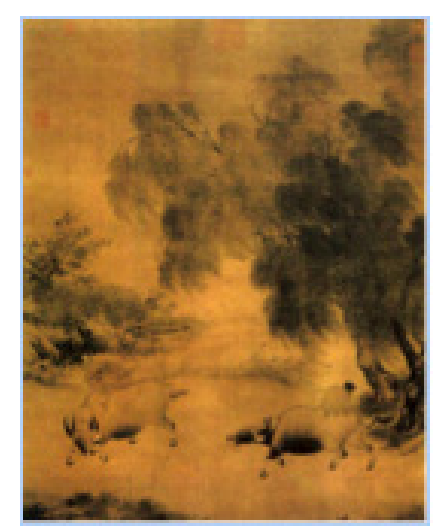

Figure 5. Li Di: returning from pasturing (Taibei Palace Museum Collection) 


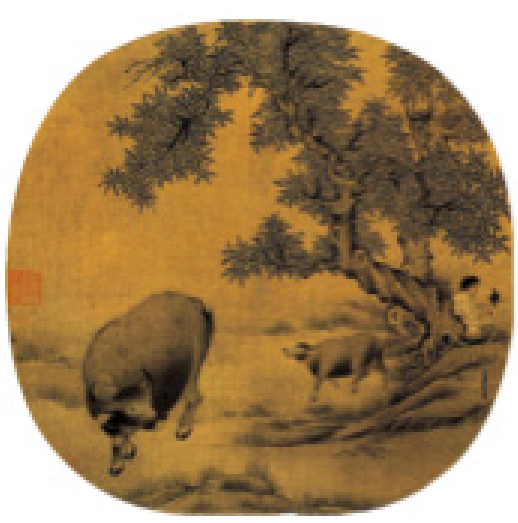

Figure 6. Lin Chun: cattle pasturing (Taibei Palace Museum Collection)

\section{Conclusion}

This paper summarizes that the reasons leading to the prosperity of the Song Genre Paintings are the emergence of the painting market and the Imperial Academy, based on the analysis on the concept and development progress of genre paintings. Besides a few folk painters, government officials and monks, most surviving genre paintings of the Song Dynasty were produced by the artists of Imperial Academy.

\section{Acknowledgements}

It is a project supported by Chinese Universities Scientific Fund. (Project Code: CUSF-DH-D-2014065)

\section{References}

Chun, D. (2000). Continuation of Category of Paintings and Calligraphies. Changsha: Hunan Fine Arts Publishing House.

Editorial Office of Encyclopedia of China. (2013). Encyclopedia of China. Beijing: Encyclopedia of China Publishing House.

Huarui, L. (1993). Primary Investigation of Painting Market of Song Dynasty. Research on Plastic Arts, 88(6), 59-63.

Roujian, S. (1987).China Art Dictionary. Shanghai: Shanghai Lexicographical Publishing House.

Ruoxu, G. (2000). Category of Paintings and Calligraphies. Changsha: Hunan Fine Arts Publishing House.

Shaoqing, L. ( 2010). Discussion on the Complex of Customs of Painters of Imperial Academys and Imperial Sponsorship of the Genre Paintings of the Southern and Northern Song Dynasties. Exhibition of Art, 55(1), 20-22.

Yi, F. (1927). Refined language Source. Beijing: Commercial Press.

\section{Copyrights}

Copyright for this article is retained by the author(s), with first publication rights granted to the journal.

This is an open-access article distributed under the terms and conditions of the Creative Commons Attribution license (http://creativecommons.org/licenses/by/3.0/). 